\title{
Study on consumer evaluation of cooked sausages
}

\author{
Kuznetsova Tatiana ${ }^{1}$, Lazarev Anton ${ }^{1}$, Chernukha Irina ${ }^{1}$, Anisimova Irina ${ }^{1}$
}

A b s t r a c t: The mapping method in the design of internal map is one of the novel and effective ways to evaluate consumer preferences. Internal map allows determining and visualizing differences in consumer preferences to foods that are being compared. It also helps to link together different information about the food item and consumer attitude to it.

The aim of this study is to investigate the possibilities of internal map's instruments to assess consumer attitude to cooked sausages. Five samples of cooked sausage "Doktorskaya", produced according to GOST R 521096-2011, which were purchased in department stores of Moscow and Moscow region (samples No 332 and No 326), the city of Kirov and Kirov region (samples No 347, No 312 and No 303), were chosen for research. Fifty one respondents took part in the consumer testing. All respondents were divided into groups: two groups according to gender (male, 19.6\%; female, 80.3\%), and two groups according to age (20 to 25 years, $76.5 \%$; 26 to 45 years, 23.5\%). All the description of sensory and other specific characteristics were discussed among the consumer groups previous to panel testing. Hedonic and additional information was collected with the aid of questionnaires. The results of consumer assessments were analysed together with additional attributes (demographic and other). The significance of the data obtained was checked with ANOVA. The data interpretation was carried out on two principal components, which explain over $70 \%$ of all data divergence.

In the first stage main sensory characteristics were analysed: appearance, colour, flavour, consistency. In the second stage some specific characteristics were analysed: "meaty" flavour, "smoky" aroma, aroma of spices, "spicy" taste and "saltiness". The obtained data demonstrated that samples No 332, No 326 and No. 347 were the leaders in terms of preference of their specific organoleptic characteristics.

It is evident that internal preference maps facilitate the analysis of the consumer panel testing results of both sensory and specific characteristics.

Summarizing the results of the study on the consumer evaluation of product quality, it can be concluded that the use of internal preference maps allows obtaining of the complex visualized information not only about overall preference of a product but also about preference of the individual organoleptic attributes and specific characteristics with regard to the market segments.

Statistical analysis of the results of consumer preferences by mapping method enables to: (1) study product classes, highlight a direction and strength of liking or disliking of a product by the specific groups of population, determine the best and similar products by organoleptic properties; (2) study consumer requirements; (3) determine a direction of product modifications to optimize its organoleptic characteristics and improve perception by consumers; - assess consumer reaction on newly developed products; (4) establish the link between the product organoleptic characteristics and consumer preferences.

The obtained information can be used by marketing services when developing a new product strategy and launching it to a market, studying a market structure, strengths and weaknesses of competitors, needs and motivation of buyers, the targeted work with a specific buyers'segment and so on.

Key words: consumer evaluation, cooked sausages, mapping method, internal preference maps, consumer preferences.

\section{Introduction}

The most important target for a product manufacturer is the production of competitive products with high consumer acceptance. One of the ways to achieve the set goal is to implement modern methods of sensory analysis which, in addition to the product quality evaluation, can also be successfully used for correction of its organoleptic properties according to consumer preferences. Thus, sensory examinations are carried out using the methods of consumer evaluation based on the study of consumer impressions of organoleptic characteristics of a given product (Meilgaard et al., 1999; Šarčević et $a l, 2011)$. Various methodologies of the approach to investigating consumer preferences and analysis of the obtained results help not only to understand the consumer attitudes toward a product, but also reveal the main purchase motivation. In the analysis of the obtained data, the multidimensional methods of statistical analysis are widely used; for example, the mapping method, which makes it possible to visualize the relationships of the sensory data array by two or three dimensional diagrams, so called the internal preference maps (Resano et al., 2009; Santa Cruz et al., 2003).

${ }^{1}$ The V.M. Gorbatov All-Russian Meat Research Institute, Talalikhina 26, Moscow, Russia.

Corresponding author: Chernukha Irina, imcher@inbox.ru 
An internal preference map presents a model reflecting relationships of consumer liking and disliking, and a product being positioned, its organoleptic characteristics, packaging and so on. The revealed relationships are indicated by the corresponding arrows as a vector directed from the zero point toward the product samples, for which consumer preferences are investigated (Meullenet et al, 2007; van Kleef, 2006). So, the described method makes it possible to establish relationships of consumer liking of a product depending on the age, gender, purchase activity, and a respondent's income. Analysis of such data gives an opportunity to improve prediction and more precisely interpret the obtained results (Guinard et al., 2001; Šarčević et al, 2013).

This study presents the detailed visualization of the relationships at the level of consumer liking a single sensory property with several additional attributes.

The applied mapping method includes questionnaire, criteria for a product and respondent selection and method of creating a map based on the data obtained as a result of the survey. The aim of this study was to evaluate the possibilities of using consumer methods of competing product evaluation based on the analysis of the internal preference maps. As an example, the analysis of the internal preference maps revealing only a part of the methodology for consumer quality evaluation is presented.

\section{Material and methods}

Five samples of cooked sausage "Doktorskaya" produced according to GOST R 521096-2011 and sold in Moscow and Moscow region (samples No 332 and No 326), the city of Kirov and Kirov region (samples No 347, No 312 and No 303) were chosen for the present study. Fifty one respondents took part in the consumer testing. The respondents were divided into groups: two groups according to the gender (male, 19.6\%; female, $80.3 \%$ ), and two groups according to the age (20 to 25 years, $76.5 \%$; 26 to 45 years, $23.5 \%$ ). Before tasting, consumers were informed about the aim of the investigation. Organoleptic properties and specific characteristics (so called, descriptors) used for evaluation of cooked sausage quality were discussed with consumers (Kuznetsova et al., 2014.). After tasting the products, the respondents filled in the questionnaires, which contained the general and specialized sections. In the general section, consumers were asked to express their preferences regarding the tested samples according to the main organoleptic attributes (appearance, taste, aroma, consistency and so on), and in the specialized section according to the specific characteristics (saltiness, taste of spices, aroma of smoking fume and so on). A graphic hedonic scale was used to assess the intensity of the organoleptic characteristics. The obtained data were analysed by multidimensional statistical methods.

Since the method of mapping is oriented to the imaging of relationships in a group of products, it is necessary to consider upon interpretation of the results that products with similar organoleptic properties are located on a map close to each other, and those that are different are at a significant distance. Vectors characterizing consumer reactions have different lengths, which reflect degrees of consumer liking.

\section{Results and discussion}

The results of consumer preference of the group of cooked sausages are presented in Fig. 1-3. The data characterizing preferences regarding the sausage appearance and colour (Fig 1a, 1 b) suggest the differentiated consumer perception of each sample (the samples are located far from each other). The figure shows that most of the vectors reflecting consumer liking of the product are directed toward the area located between samples No. 326 and No. 332. Analysis of the established relationships demonstrated that no sausage sample corresponded in full measure to the consumer liking and the most desirable for them was the combination of the appearance and colour characteristics typical of sausage samples No. 326 and No. 332. The obtained information can serve as a guide for a producer in optimization of appearance and colour of a product being manufactured.

The visualization of the preferences regarding attribute "taste of sausages" suggests that the preference spectrum for the majority of consumers is directed toward the area located between samples No. 332 and No. 347 (Fig. 1 c, d) and preference regarding the attributes "aroma" and "consistency" toward samples No. 332 and No. 326. Samples No. 303 and No. 312 were in the area of disliking for almost all organoleptic attributes.

The data presented in Fig. 1 a-e demonstrate no specific directions or clusters of preferences, which suggests the absence of a clear gradation dependent on age.

Appearance and colour of sample No. 326 were more attractive for the middle-aged people but they preferred sample No. 347 in terms of taste. 

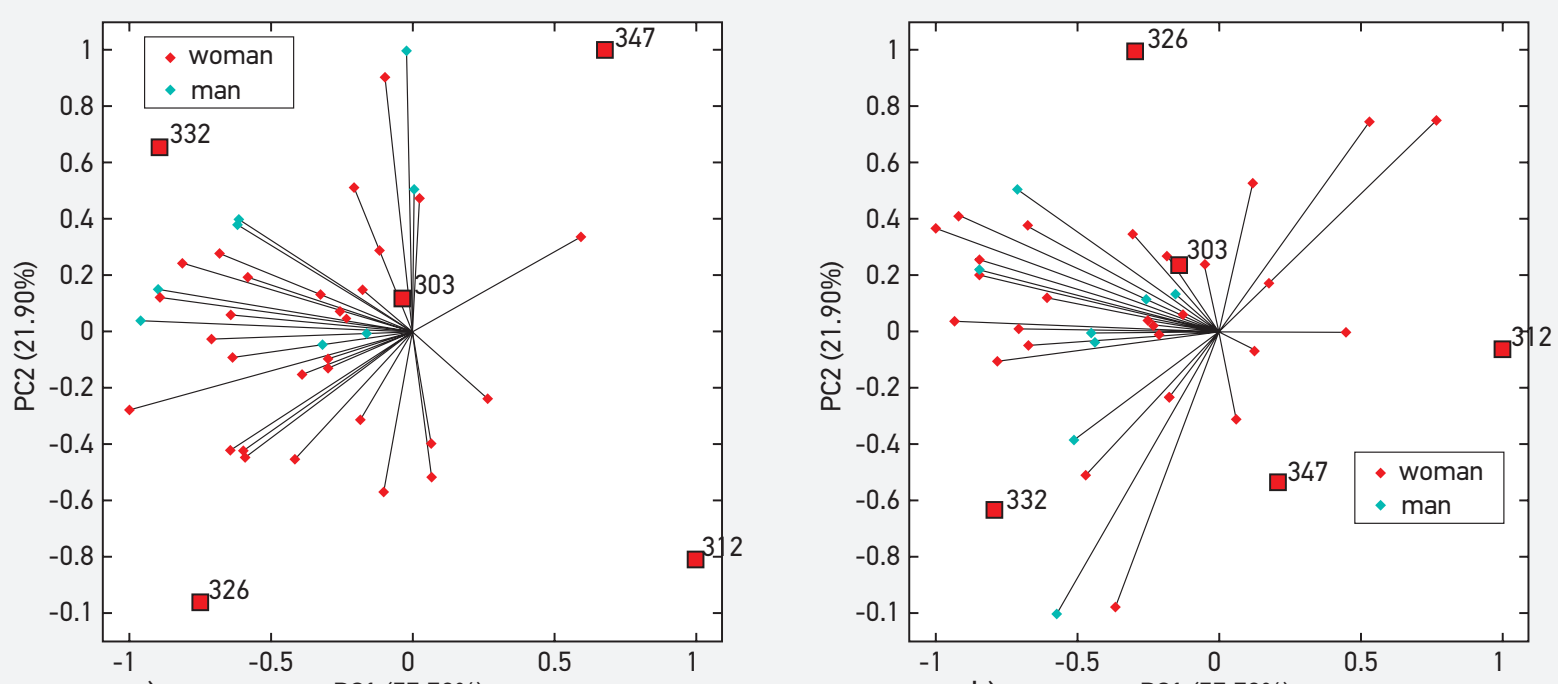

a)

PC1 $(57.70 \%)$

b)
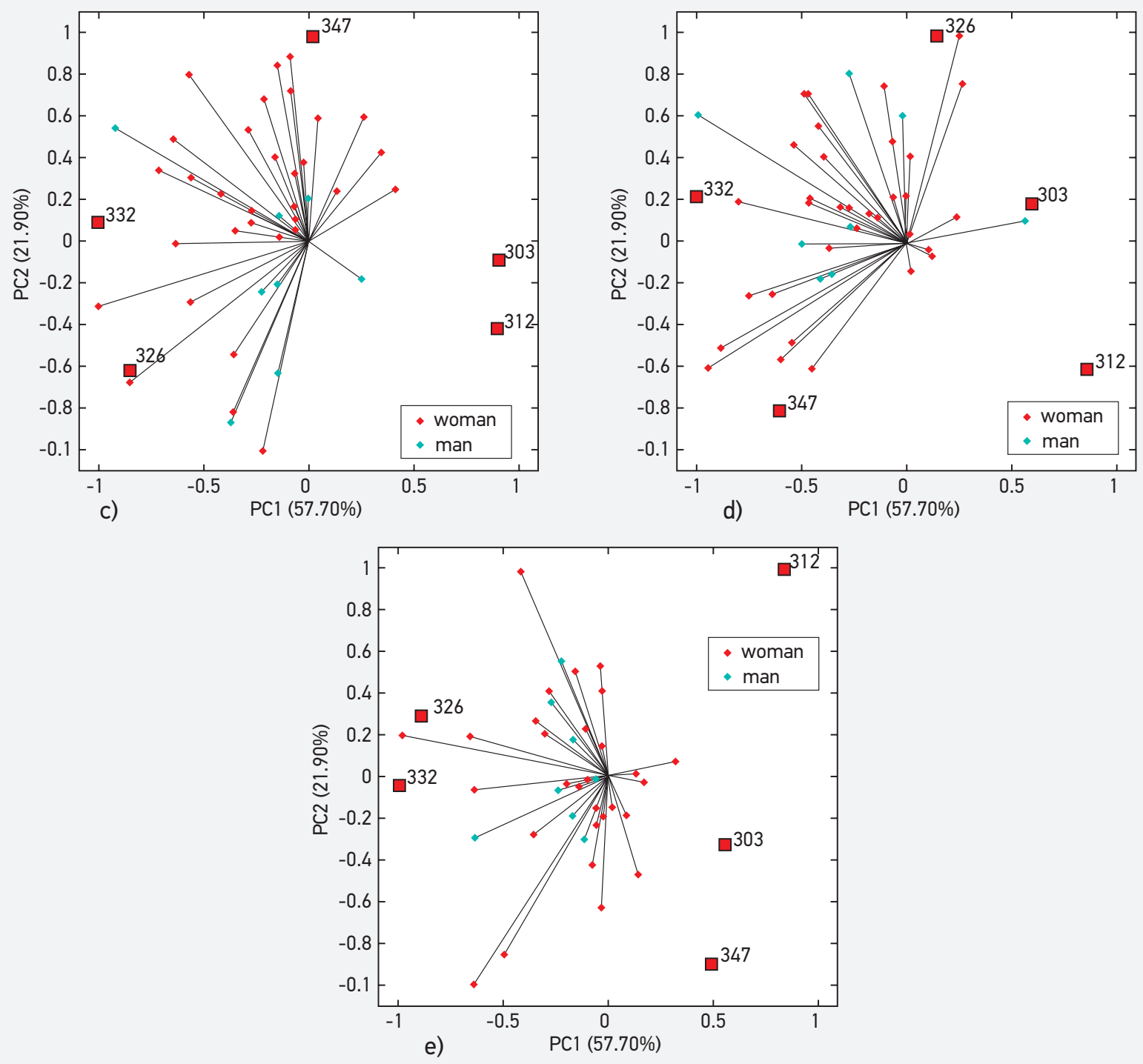

Figure 1. Internal preference maps by attributes: a) appearance; b) cut-surface colour c) taste; d) aroma; e) consistency.

Slika 1. Interne/unutrašnje mape prema osobinama: a) izgled; b) boja preseka; c) ukus; d) aroma; e) konzistencija 

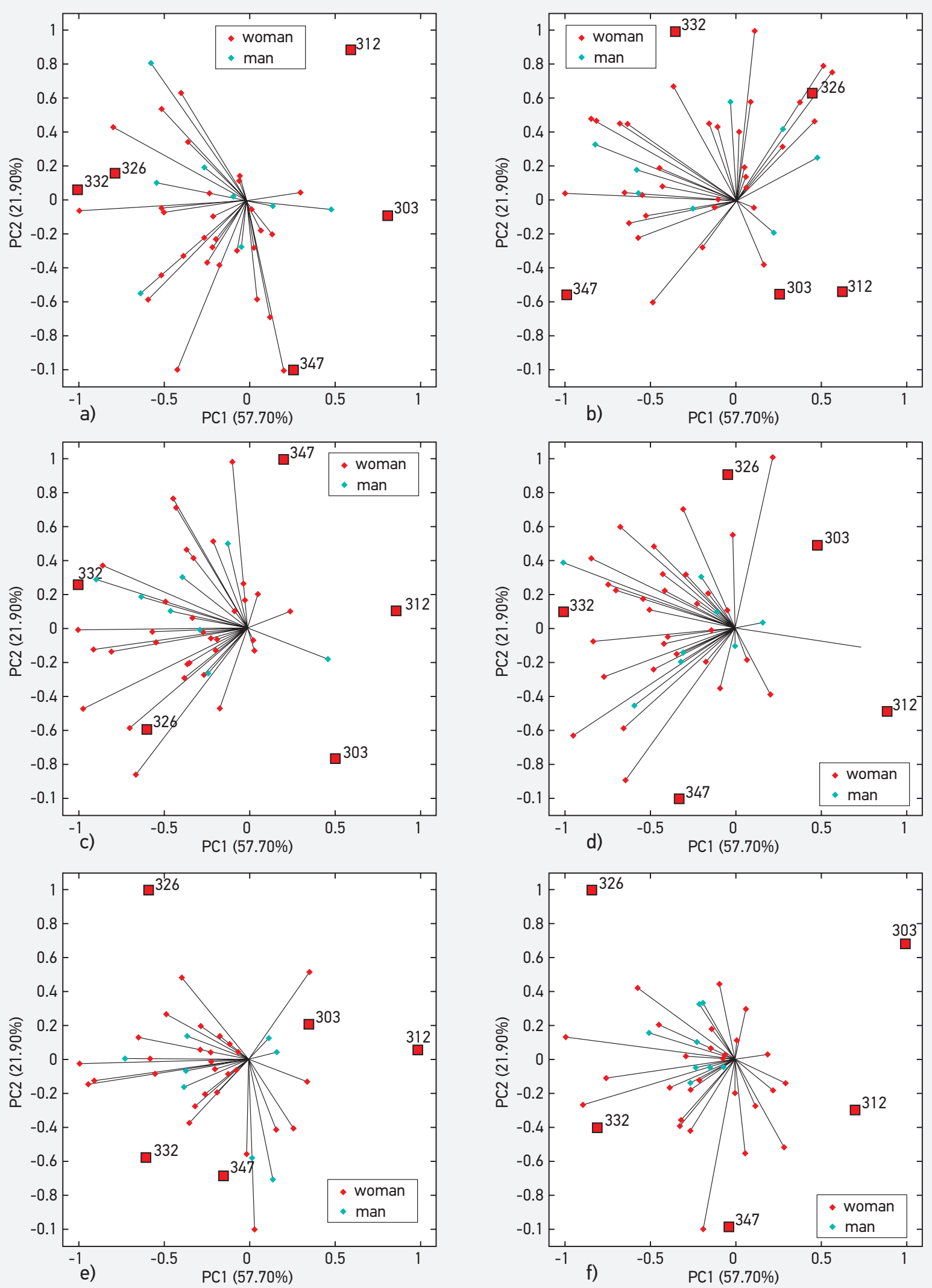

Figure 2. Internal preference maps by sensory attributes: a) "meaty taste", b) "meaty aroma", c) "aroma of smoking", d) "aroma of spices", e) "aste of spices", f) "saltiness" for cooked sausages Doktorskaya.

Slika 2. Interne/unutrašnje mape prema senzornim osobinama: a) „,mesnati ukus“, b) „mesnata aroma“, c) ,aroma dimljenog proizvoda“, d) ,aroma začina“, e) ,začinjenost“", f), ,slanoća“ kuvanih kobasica Doktorskaya. 
The differences in liking depending on the frequency of product consumption were established.

Thus, the absolute leaders in terms of consumer preference are samples No. 332 and No. 326. However, sample No. 347 cannot be assigned to the preference outsiders because the consumers of the older age group liked it mostly as they are used to that sausage. They have consumed it over a long period of time.

The second stage of the investigations consisted in the analysis of consumer preferences with regard to the specific organoleptic characteristics such as "meaty" taste and aroma, "aroma of smoking" and "aroma of spices", "taste of spices" and "saltiness", which are important attributes for assessment of its competitiveness.

Analysis of consumer preferences regarding "meaty" taste for cooked sausages showed that samples differed significantly from each other in their perception, with the exception of samples No. 332 and No. 326 (Fig. 2a). The proximity of the location of the latter two to each other suggests that consumers do not feel any significant differences between the samples in terms of this organoleptic characteristic and perceive them equally. Most of liking was directed towards samples No. 326, No. 332 and No. 347.

The aroma of smoking, its intensity and various hints can affect both positively and negatively the appeal of a product. Excessive intensity or unpleasant hint plays an important role in the competitiveness of a product.

The preference map shows that the consumers perceived products differently (Fig. 2c). The majority of the consumers liked the aroma of samples No. 326, No. 332 and No. 347, while samples No. 312 and No. 303 were in the disliking zone. The similar picture shows the perception for sausage "aroma of spices" (Fig. 2d).

Analysis of preferences according to attribute "saltiness" (Fig. 2e) shows that the spectrum of liking is distributed between samples No. 326 , No. 332 and No. 347. If we consider liking of this characteristic with regard to the additional attributes (for example, gender), the group of male respondents was recognizably distinct with their preferences located in the direction toward samples No.332 and No. 326, which are saltier.

The obtained data demonstrated that samples No 332, No 326 and No. 347 were the leaders in terms of liking for the specific organoleptic characteristics.

\section{Conclusion}

Summarizing the results of the study on the consumer evaluation of product quality, it can be concluded that the use of internal preference maps allows obtaining of the complex visualized information not only about overall liking of a product but also about liking of the individual organoleptic attributes and specific characteristics with regard to the market segments.

Statistical analysis of the results of consumer preferences by mapping method enables to:

- $\quad$ study product classes, highlight a direction and strength of liking or disliking of a product by the specific groups of population, determine the best and similar products by organoleptic properties;

- tudy consumer needs;

- determine a direction of product modifications to optimize its organoleptic characteristics and improve perception by consumers;

- $\quad$ assess consumer reaction on newly developed products;

- establish relationships of product organoleptic characteristics and consumer preferences.

The obtained information can be used by marketing services when developing of a new product strategy and launching it to a market, studying a market structure, strengths and weaknesses of competitors, needs and motivation of buyers, the targeted work with a specific buyers' segment and so on. 


\title{
References
}

Guinard J. X., Uotani B., Schlich P., 2001. Internal and external mapping of preferences for commercial lager beers: comparison of hedonic ratings by consumers blind versus with knowledge of brand and price. Food Quality and Preference, 12, 243-255.

Kuznetsova T. G., Lazarev A. A., Anisimova I. G., 2014. Comparison of main sensory characteristics of cooked sausages. «Myasnaja Industrija», № 4, 32-34.

Meilgaard M, Civille G. V., Carr B. T., 1999. Sensory Evaluation Techniques, 3nd ed. Boca Raton, Florida: CRC Press LLC, 231-234.

Meullenet J. F., Xiong R., Findlay C. J., 2007. Multivariate and probabilistic analyses of sensory science problems. Ames, IA: Blackwell Publishing. P. 51.

Resano H., Sanjuán A. I., Albisu L. M., 2009. Consumers' acceptability and actual choice: An exploratory research on cured ham in Spain. Food Quality and Preference, 20, 391-398.
Santa Cruz M. J., Garitta L. V., Hough G., 2003. Note: Relationships of consumer acceptability and sensory attributes of Yerba mate (Ilex paraguariensis St. Hilaire) using preference mapping. Food Science and Technology International, 9, 346-347.

Šarčević D., Đorđević V., Petronijević R., Matekalo-Sverak V., Karabasil N., Popović Lj., Janković V., 2013. The attitudes and habits of Serbian schoolchildren in consumption of meat. Tehnologija mesa, 54, 2, 160-167.

Šarčević D., Lilić S., Đorđević V., Milićević D., Vranić D., Lakićević B., Milijašević M., 2011. The role of consumers' perception and attitude in purchasing of meat and meat products. Tehnologija mesa 52, 2, 283-290.

van Kleef E., van Trijp H. C. M., Luning P., 2006. Internal versus external preference analysis: An exploratory study on end-user evaluation. Food Quality and Preference, 17, 387-399.

\section{Studija o proceni kvaliteta kuvanih kobasica od strane potrošača}

\author{
Kuznetsova Tatiana, Lazarev Anton, Chernukha Irina, Anisimova Irina
}

R e z i m e: Metod mapiranja u dizajnu internih mapa je jedan od novih i efikasnih načina za procenu stava potrošača prema proizvodima. Interna mapa omogućava da se utvrde i vizualizuju razlike u preferencama potrošača prema hrani koja se poredi. Mapa, takođe, pomaže da se povežu različite informacije o proizvodu i stavu potrošača prema njemu.

Cilj ove studije bio je da se istraže mogućnosti interne mape radi procene stava potrošača prema kuvanim kobasicama. Pet uzoraka kuvane kobasice „Doktorskaya“ koja je proizvedena u skladu sa GOST R 521096-2011, a koji su kupljeni u prodavnicama u Moskvi i moskovskom regionu (uzorci br. 332 i br. 326), i u gradu Kirov i Kirovskom regionu (uzorci br. 347, br. 312 i br.303) su izabrani za istraživanje. Pedeset jedan ispitanik je učestvovao u testiranju. Ispitanici su bili podeljeni u grupe: dve grupe prema polu (muškarci, 19,6\%; žene, 80,3\%), i dve grupe prema uzrastu (20 do 25 godina, 76,5\%, 26 do 45 godina, 23,5\%). Opisi senzornih $i$ drugih specifičnih karakteristika su razmatrani među potrošačima u grupama pre panel testiranja. Hedonističke i dodatne informacije su prikupljene uz pomoć upitnika. Rezultati ocene potrošača su analizirani, zajedno sa dodatnim atributima (demografskim i dr.). Značajnost dobijenih podataka je testirana upotrebom ANOVA. Podaci su tumačeni pomoću dve glavne komponente, koje opisuju više od 70\% ukupne varijabilnosti podataka.

U prvoj fazi, analizirane su glavne senzorne osobine: izgled, boja, ukus i konzistentnost. U drugoj fazi, analizirane su neke specifične karakteristike: aroma mesa, aroma dima, aroma začina, ,,ljut“ ukus i ,,slanost“. Dobijeni podaci su pokazali da su uzorci br. 332, br. 326 i br. 347 imali vodeću poziciju u smislu sklonosti potrošača ka specifičnim organoleptičkim osobinama proizvoda.

Evidentno je da interna mapa preferenci omogućava analizu rezultata panel testiranja potrošača, kako senzornih, tako i specifičnih karakteristika.

Sumirajući rezultate studije o evaluaciji kvaliteta proizvoda od strane potrošača, može da se zaključi da upotreba interne mape preferenci omogućava dobijanje kompleksne vizuelne informacije, ne samo o ukupnom ukusu nekog proizvoda, već i o sklonosti potrošača ka pojedinačnim organoleptičkim osobinama i specifičnostima, a u vezi sa segmentima tržišta.

Statistička analiza rezultata preferenci potrošača metodom mapiranja omogućava: (1) ispitivanje kategorija proizvoda, označavanje pravaca i sklonosti ili odsustvo sklonosti ka nekom proizvodu, određivanje najboljih proizvoda i proizvoda sličnih organoleptičkih svojstava; (2) ispitivanje zahteva potrošača; (3) određivanje pravca modifikovanja proizvoda u cilju optimizovanja organoleptičkih osobina i poboljšavanja percepcije potrošača; procenu stava potrošača o novorazvijenim proizvodima; (4) uspostavljanje veze između organoleptičkih osobina proizvoda i preference potrošača.

Dobijene informacije mogu koristiti marketinškim službama prilikom izrade strategije novih proizvoda i njihovog plasmana na tržišse, proučavajući tržišne strukture, prednosti i slabosti konkurenata, potreba i motivacija kupaca, ciljani rad sa segmentom specifičnih kupaca, i tako dalje.

Ključne reči: procena potrošača, kuvane kobasice, metod mapiranja, interna mapa preferenci, preference potrošača. 